\title{
DETECTION OF SER450LEU MUTATION IN RPOB GENE OF MYCOBACTERIUM TUBERCULOSIS BY ALLELE-SPECIFIC LOOP-MEDIATED ISOTHERMAL DNA AMPLIFICATION METHOD
}

Filipenko ML ${ }^{1} \otimes$, Oscorbin IP ${ }^{1}$, Khrapov EA ${ }^{1}$, Shamovskaya DV ${ }^{1}$, Cherednichenko AG $^{2}$, Shvartz YaSh ${ }^{2}$

${ }^{1}$ Institute of Chemical Biology and Fundamental Medicine, Novosibirsk, Russia

${ }^{2}$ Novosibirsk Tuberculosis Research Institute, Novosibirsk, Russia

To identify genetic mutations a rather time-consuming and expensive method of polymerase chain reaction (PCR) is widely used. The aim of the present work was to evaluate the possibility of using the two schemes of the method of allele-specific isothermal loop amplification (LAMP) to detect the TCG/TTG (S450L) mutation in the rpoB gene of Mycobacterium tuberculosis. 48 clinical isolates of $M$. tuberculosis and 11 samples of sputum were used, randomized and obtained in the microbiological laboratory of the city of Novosibirsk from incident patients. It is shown that the use of an analysis scheme using the allele-specific primer FIP compared to F3 has the best resolution: the difference between the amplification time of the mutation and the wild type allele was $22 \pm 2,4$ versus $13 \pm 4,1$ minutes $(p=0,0011)$. When using 100 DNA genomic equivalents a true positive signal (amplification of the rpoB gene with a mutation using the corresponding allele-specific primer) was detected after 29,4 $\pm 3,4$ minutes. A positive signal was visualized after adding SYBR Green I to the reaction, both when illuminated with daylight and

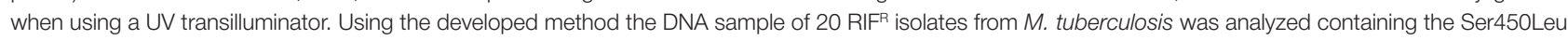
mutation in the rpoB gene, $10 \mathrm{RIF}^{\mathrm{R}}$ isolates containing other mutations in the rpoB gene and $18 \mathrm{RIF}^{\mathrm{s}}$ isolates without any mutations; the presence of mutations in the samples was determined using classical Sanger sequencing. The sensitivity and specificity of LAMP for detecting a Ser450Leu mutation in the rpoB gene was $100 \%$. This approach allows the use of crude lysates of mycobacteria as DNA, which reduces the total analysis time to 1,5 hour.

Keywords: Mycobacterium tuberculosis, drug resistance, rifampicin, rpoB gene, isothermal loop amplification, LAMP

Funding: the study was done with the financial support of the basic budgetary financing project № VI.62.1.5 «Synthetic biology: development of tools for the genetic material manipulation and creation of promising drugs for therapy and diagnostics» (0309-2018-0003).

Author contribution: Filipenko ML created a general concept of the study, planned experiments, analyzed the results and participated in the writing of this article; Oscorbin IP participated in the writing of this article; Khrapov EA conducted experiments; Shamovskaya DV conducted experiments; Cherednichenko AG analyzed the experiments results; Shvartz YaSh was involved in planning and analyzed the experiments results.

Compliance with ethical standards: the study was approved by the Ethics Committee of Institute of Chemical Biology and Fundamental Medicine (Protocol 4 dated April 09, 2009). All patients signed a voluntary informed consent to participate in the study.

Correspondence should be addressed: Maxim L. Filipenko

Lavrentyev Prospect 8/2, Novosibirsk, 630090; mlfilipenko@gmail.com

Received: 07.12.2018 Accepted: 25.02.2019 Published online: 09.03.2019

DOI: $10.24075 /$ brsmu.2019.007

\section{ВЫЯВЛЕНИЕ МУТАЦИИ SER450LEU В ГEHE RPOB MYCOBACTERIUM TUBERCULOSIS МЕТОДОМ АЛЛЕЛЬ-СПЕЦИФИЧНОЙ ИЗОТЕРМИЧЕСКОЙ ПЕТЛЕВОЙ АМПЛИФИКАЦИИ ДНК}

М. Л. Филипенко ${ }^{\circledR}$, И. П. Оскорбин ${ }^{1}$, Е. А. Храпов ${ }^{1}$, Д. В. Шамовская ${ }^{1}$, А. Г. Чередниченко², Я. Ш. Шварц²

${ }^{1}$ Институт химической биологии и фундаментальной медицины СО РАН, Новосибирск, Россия

2 Новосибирский научно-исследовательский институт туберкулеза, Новосибирск, Россия

Для выявления генетических мутаций широко используют достаточно трудоемкий и дорогостоящий метод полимеразной цепной реакции (ПЦР). Целью работы было оценить возможность применения двух схем метода аллель-специфичной изотермической петлевой амплификации (Іоор-теdiated isothermal amplification, LAMP) для выявления мутации TCG/TTG (S450L) в гене rроB Мусоbacterium tuberculosis. Использовали 48 клинических изолятов M. tuberculosis и 11 образцов мокроты, выбранных случайным образом и полученных в микробиологической лаборатории г. Новосибирска от пациентов с впервые выявленным заболеванием. Показано, что применение схемы анализа с использованием аллель-специфичного праймера FIP по сравнению c F3 имеет лучшую разрешающую способность: разница между временем амплификации мутации и аллеля дикого типа составила $22 \pm 2,4$ против $13 \pm 4,1$ мин ( $p=0,0011)$. При использовании 100 геном-эКвивалентов ДНК истинно положительный сигнал (амплификация гена гроВ с мутацией при использовании соответствующего аллель-специфического праймера) детектировался после 29,4 \pm 3,4 мин. Положительный сигнал визуализировался после добавления в реакцию SYBR Green I, как при освещении дневным светом, так и при использовании трансиллюминатора с УФ-излучением. C помощью разработанного нами метода была проанализирована выборка ДНK 20 RIFR изолятов M. tuberculosis, неcyщих мyтацию Ser450Leu в гене rpoB, $10 \mathrm{RIF}^{\mathrm{R}}$ изолятов, несущих другие мутации в гене rроB, а также $18 \mathrm{RIF}^{\mathrm{s}}$ изолятов без мутаций; наличие мутаций в образцах было определено с помощью классического секвенирования по Сенгеру. Чувствительность и специфичность LAMP для выявления мутации Ser450Leu в гене rроB составили 100\%. Данный подход позволяет использовать в качестве ДНК грубые лизаты микобактерий, что сокращает тотальное время анализа до 1,5 ч.

Ключевые слова: Mycobacterium tuberculosis, лекарственная устойчивость, мутации, рифампицин, ген гроВ, изотермическая петлевая амплификация, LАМР

Финансирование: работа выполнена при финансовой поддержке проекта базового бюджетного финансирования № VI.62.1.5 «Синтетическая биология: разработка средств манипуляции генетическим материалом и создание перспективных препаратов для терапии и диагностики" (0309-2018-0003).

Информация о вкладе авторов: М. Л. Филипенко - общий замысел работы, планирование экспериментов, анализ результатов экспериментов, написание статьи; И. П. Оскорбин - написание статьи; Е. А. Храпов - проведение экспериментов; Д. В. Шамовская - проведение экспериментов; А. Г. Чередниченко - анализ результатов экспериментов; Я. Ш. Шварц — планирование и анализ результатов экспериментов.

Соблюдение этических стандартов: исследование одобрено комитетом по медицинской этике Института химической биологии и фундаментальной медицины СО РАН (№ 4 от 9 апреля 2009 г.). Все пациенты подписали добровольное информированное согласие на участие в исследовании.

$\triangle$ Для корреспонденции: Максим Леонидович Филипенко

пр. академика Лаврентьева, д. 8/2, г. Новосибирск, 630090; mlfilipenko@gmail.com

Статья получена: 07.12.2018 Статья принята к печати: 25.02.2019 Опубликована онлайн: 09.03.2019

DOI: 10.24075/vrgmu.2019.007 
Through many centuries tuberculosis is among the most difficult in treatment infectious diseases with high mortality. Now drug-resistant (DR) isolates of $M$. tuberculosis are a threat to public health: they complicate conservative treatment, lead to patient disability, and the growth and spread of DR-strains among healthy populations is observed. This determines the necessity of the development of effective and possibly simple methods for detecting drug resistance of mycobacteria. One of the widely used first-line anti-TB drugs in the treatment of tuberculosis is rifampicin. Resistance to rifampicin is often considered as a surrogate marker of multidrug resistance (MDR) of the tuberculosis mycobacterium complex [1]. Rifampicin was introduced into the phthisiatricians clinical practice in 1972. It is highly effective against Mycobacterium tuberculosis, the minimal inhibiting concentration (MIC) of rifampicin is $0,1-0,2 \mu \mathrm{g} / \mathrm{ml}$ [2]. In combination with isoniazid and pyrazinamide rifampicin is the base of pharmacotherapy of the tuberculosis infection.

The cell target of rifampicin is the DNA-dependent RNA polymerase enzyme, which is extremely conservative among bacteria and archaea. The overwhelming majority of mutations responsible for rifampicin resistance are localized in three regions of the rpoB gene, encoding the beta subunit of the RNA polymerase: cluster I (encodes 512-534 amino acid positions), cluster II (563-574), and cluster III (687). In 95\% of cases, mutations affect cluster I or the so-called rifampicin-resistance determining region (RRDR) consisting of 81 base pairs. This region corresponds to codons 426-452 in Mycobacterium tuberculosis and 507-533 in Escherichia coli. Traditionally designated by the $E$. coli nomenclature mutations in codons 521, 526, 531 and 533 (positions 440, 445, 450 and 452 in the rpoB gene of Mycobacterium tuberculosis) are the most common for rifampicin-resistant Mycobacterium tuberculosis [3].

Amino acid substitutions at positions 526 and 531 lead to resistance to high doses of rifampicin. Amino acid substitution Ser450Leu (S450L, nomenclature of the Mycobacterium tuberculosis gene, which will be used in the present article) dominates among all other substitutions, determining resistance in $30-70 \%$ of rifampicin-resistant $\left(\mathrm{RIF}^{\mathrm{R}}\right)$ isolates (the median is about 60\%) [3]. This makes the S450L mutation (TCG/TTG) the most significant candidate for the validation of a wide variety of genetic screening methods for detection of Mycobacterium tuberculosis resistance to rifampicin $[4,5]$.

Today, the most commonly used method for detecting genetic mutations is the polymerase chain reaction (PCR). This method is simple to perform, and demonstrates enough reliability. PCR modifications using monitoring of specific amplicons by detecting accumulation of a fluorescent signal (real time PCR) make the analysis homogeneous and allow to avoid additional manipulations with the amplicon extra vitro. However, PCR is performed using rather complicated and expensive instruments. This was the reason for the development of alternative methods of nucleic acids amplifying, primarily feasible under isothermal conditions [6].

In 2000 the loop-mediated isothermal amplification (LAMP) method was developed. Initially, the method assumed the use of two pairs of primers (outer and inner) and DNA polymerase with chain-displacing activity [7]. Later, the developers introduced an additional pair of primers to improve the amplification kinetics.

In specificity and sensitivity LAMP (the limit of sensitivity is around several DNA molecules) is comparable to PCR, and in some cases takes precedence over it. The increased resistance of LAMP to the PCR inhibitors was also noted [8]. For the detection of LAMP results, approaches based on different principles can be used. First of all it is the measurement of optical density due to magnesium pyrophosphate formed during DNA synthesis [9], or the fluorescence measurement in response to introduction of the intercalating dyes [9], primer modification [10] or the introduction of fluorescently-labeled probes [11], as well as colorimetric detection of metal-sensitive dyes due to the binding of magnesium ions by pyrophosphate [12].

To date, a significant amount of research has been done on the development of test systems for detecting Mycobacterium tuberculosis using LAMP [13]. The Loopamp MTBC Detection Kit (Eiken Chemical Company Ltd; Japan) based on the LAMP method has been noted by WHO as a possible replacement for microscopic examination for the diagnosis of tuberculosis [14]. It was also recommended as an additional to microscopy test in the diagnosis of adults with clinical symptoms of tuberculosis, including the diagnosis of negative according to the results of microscopy patients. However, the use of LAMP for detection of mutations of Mycobacterium tuberculosis causing drug resistance has not yet been described.

The aim of our work was to develop a method for detecting TCG/TTG mutation (S450L) in the rpoB gene of Mycobacterium tuberculosis for detection of rifampicin resistance without using expensive equipment, and also to evaluate the effectiveness of two types of the allele-specific isothermal loop amplification (AS-LAMP) design, and to determine the optimal system's analytical characteristics on a representative DNA sample of Mycobacterium tuberculosis isolates.

\section{METHODS}

\section{Clinical isolates}

Clinical isolates from $M$. tuberculosis (48 isolates) as well as 11 sputum samples were selected randomly and obtained in the microbiological laboratory of the Novosibirsk Tuberculosis Research Institute, Novosibirsk, from the patients living in the city of Novosibirsk and the Novosibirsk region, who were examined in 2009-2011. The taking and processing of sputum was carried out in accordance with the $\mathrm{MOH}$ order № 109 of 21.03.2003 (edition of 29.10.2009). Criteria for inclusion of patients in the study: males and females of any age; incident patients; rifampicin resistance presence. Exclusion criteria: not a newly diagnosed disease; rifampicin resistance absence. Rifampicin resistance $(40 \mu \mathrm{g} / \mathrm{ml})$ was determined according to the absolute concentrations method on a Lowenstein-Jensen medium. Isolate resistance to rifampicin was determined in the BACTEC MGIT 960 fluorometric system (Becton-Dickinson; USA). Crude lysates as well as DNA from bacterial colonies of isolates were obtained by heating in $300 \mu \mathrm{l}$ of buffer containing $10 \mathrm{mmol}$ of sodium tetraborate $(\mathrm{pH} 9.5)$ and $1 \%$ 2-methoxyethanol during 10 minutes at $98^{\circ} \mathrm{C}$ followed by centrifugation to precipitate cellular debris.

\section{Sequencing of rpoB gene}

For amplification of the 322 nucleotide pairs rpoB gene fragment the rpoB1 5'-AACCGCCGCCTGCGTACGGT-3' and rpoB2 5'-GGCCGTAGTGCGACGGGTGCA-3' primers were used. The reaction mixture of $25 \mu \mathrm{l}$ contained $65 \mathrm{mmol}$ of Tris- $\mathrm{HCl}(\mathrm{pH} 8,9), 16 \mathrm{mmol}$ of $\left(\mathrm{NH}_{4}\right)_{2} \mathrm{SO}_{4}, 3 \mathrm{mmol}$ of $\mathrm{MgCl}_{2}, 0,05 \%$ Tween-20, 0,2 mmol of dNTP, one unit of Taqpolymerase (Fermentas; Lithuania), 0,3 $\mathrm{mmol}$ of mentioned above oligonucleotide primers and $1-10 \mathrm{ng}$ of genome DNA from M. tuberculosis. Amplification was performed in the PTC200 amplifier (BioRad; USA) using the following program: $96^{\circ} \mathrm{C}-$ 3 minutes, then 35 cycles at $95^{\circ} \mathrm{C}-10$ seconds, $64^{\circ} \mathrm{C}-$ 10 seconds and $72{ }^{\circ} \mathrm{C}-20$ seconds with final elongation at 
$72{ }^{\circ} \mathrm{C}-3$ minutes. The presence of amplification product of the required size was checked by electrophoresis in 6\% polyacrylamide gel with visualization of DNA fragments with ethidium bromide using the UV irradiation. The sequence of the PCR products was determined at the SB RAS Genomics Core Facility using the sequencing reagents from the Big Dye Terminator v3.1 Cycle Sequencing Kit (Life Technologies; USA) and the capillary electrophoresis unit ABI 3130xI Genetic Analyzer (Life Technologies; USA) according to manufacturer's instructions. Mutations were detected by comparing the obtained nucleotide sequences with the rpoB gene of M. tuberculosis (H37Rv) using the Unipro UGENE software 1.11.3 (Unipro; Russia).

\section{Obtaining of standard plasmid samples carrying frequent mutations}

The 505 nucleotide pairs DNA fragment was obtained using using amplification with oligonucleotide primers cl-rpobU and cl-rpobR (Table 1) in the following conditions: the PCR reaction mixture of $50 \mu$ contained the buffer for Taqpolymerase $65 \mathrm{mmol}$ TrisHCl; $\mathrm{pH} 8,9 ; 16 \mathrm{mmol}\left(\mathrm{NH}_{4}\right)_{2} \mathrm{SO}_{4} ; 0,05 \%$ Tween-20; 3,5 mmol $\left.\mathrm{MgCl}_{2}\right), 0,2 \mathrm{mmol}$ of dNTP, $10 \mathrm{ng}$ of genome DNA from Mycobacterium tuberculosis $\mathrm{H} 37 \mathrm{Rv}$ or DNA isolate with a TCG/TTG (S450L) mutation in the rpoB gene, one activity unit of Taq-polymerase (Biosan; Russia). Amplification was performed in the Tercyc amplifier (DNA-Technology; Russia) according to the following program: 3 minutes at $95^{\circ} \mathrm{C}$ for initial denaturation, then 34 cycles: 10 seconds at $95{ }^{\circ} \mathrm{C}$ for denaturation, 10 seconds at $60{ }^{\circ} \mathrm{C}$ for primer hybridization, 20 seconds at $72{ }^{\circ} \mathrm{C}$ for elongation. Amplification products were hydrolyzed with restriction endonucleases Hind III and BamHI (Sibenzyme; Russia) ligated with the pBluescript II SK
(+) vector that was hydrolyzed with the same endonucleases, during 8 hours with 100 activity units of T4 DNA-ligase (Biosan; Russia). Using the ligase mixture competent cells from $E$. coli of the XL1Blue strain (Stratagene; USA) were transformed. In plasmid clones selected from the results of restriction analysis, to confirm the structure, the nucleotide sequence of the insert was determined by Sanger sequencing. Sequencing was performed in the $\mathrm{ABI} 3130 \mathrm{XL}$ GeneticAnalyzer automatic sequencer (Applied Biosystems; USA) using the BigDye 3.1 kit (SB RAS Genomics Core Facility; Russia). Plasmid recombinant DNA pRPOB-M and pRPOB-W were isolated from $50 \mathrm{ml}$ of night culture in LB medium using the QIAGEN Plasmid Midi Kit (QIAGEN; Germany) according to manufacturer's instructions.

The concentration of the obtained standard plasmid DNA was determined by spectrophotometry and fluorometry using the Qubit ${ }^{T M}$ BR kit (Invitrogen; USA). Then $2 \mu \mathrm{g}$ of DNA were subjected to hydrolysis by Hindlll restriction endonuclease for linearization. The resulting linear standards were diluted to concentration of 105 and further to concentration of $5 \times 10^{2}$ plasmid DNA copies for $1 \mu \mathrm{l}$ in sterile buffer, containing $10 \mathrm{mmol}$ of Tris $\mathrm{HCl}(\mathrm{pH} 7,6)$ and $5 \mathrm{ng} / \mathrm{\mu l}$ of lambda phage DNA.

The DNA concentration in the obtained standards was refined using digital PCR in the $\mathrm{QX100}{ }^{\mathrm{TM}}$ Droplet Digital ${ }^{\mathrm{TM}}$ PCR System (Bio-Rad; USA) according to manufacturer's instructions. To do this, $20 \mu \mathrm{l}$ of PCR mixture containing the test DNA (about $10^{3}$ per $\left.20 \mu \mathrm{l}\right), 1 \times$ PCR mixture (Bio-Rad; USA), $300 \mathrm{nmol}$ olygonicleotide primers Bla-U, Bla-R and $100 \mathrm{nmol}$ TaqMan Bla-P probe for beta-lactamase gene amplifying (Table 1) were prepared. To obtain microdroplets, $20 \mu \mathrm{l}$ of the prepared PCR mixture and $70 \mu \mathrm{l}$ of oil needed to generate droplets were placed in the corresponding wells of the DG8 cartridge. Then, $40 \mu \mathrm{l}$ of the obtained microdroplets were transferred to a 96well PCR plate, sealed with foil and placed in an amplifier.

Table 1. List of oligonucleotide primers and fluorescently labeled probes used in present study

\begin{tabular}{|c|c|c|}
\hline & Name & Nucleotide sequence \\
\hline & \multicolumn{2}{|r|}{ AS-FIP design } \\
\hline 1 & $450-\mathrm{F3}$ & 5'-CCAGAACAACCCGCTGTCG-3' \\
\hline 2 & 450-B3 & 5'-TGACCCGCACGTACACCGACA-3' \\
\hline 3 & 450a-FIP-M & 5'-GGACCTCCAGCCCGGCACACCCACAAGCGCCGACTGCT-3' \\
\hline 4 & 450a-FIP-W & 5'-GGACCTCCAGCCCGGCACACCCACAAGCGCCGACTGGC-3' \\
\hline 5 & 450a-FIP-rpoB & 5'-GGACCTCCAGCCCGGCACACCCACAAGCGCCGACTG-3' \\
\hline 6 & 450a-BIP & 5'-TGCACCCGTCGCACTACGGGCCGATCAGACCGATGTTGG-3' \\
\hline 7 & 450a-LF & 5'-CCGATCGAAACCCCTGAGG-3' \\
\hline \multirow[t]{2}{*}{8} & $450 \mathrm{a}-\mathrm{LB}$ & 5'-CACGTGACAGACCGCCG-3' \\
\hline & \multicolumn{2}{|r|}{ AS-F3 design } \\
\hline 9 & 450b-F3m & 5'-CCACAAGCGCCGACTGCT-3' \\
\hline 10 & $450 b-F 3 w$ & 5'-CCACAAGCGCCGACTGGC-3' \\
\hline 11 & 450b-FIP & 5'-CACGTCGCGGACCTCCAG-GCGCTGGGGCCCGGC-3' \\
\hline 12 & 450b-BIP & 5'-ACCCGTCGCACTACGGC-GATCAGACCGATGTTGGGC-3' \\
\hline 13 & 450b-B3 & 5'-CGTACACCGACAGCGAGC-3' \\
\hline 14 & 450b-531-LF & 5'-CCGATCGAAACCCCTGAGG-3' \\
\hline 15 & 450b-LB & 5'-CCCGGCACGCTCACGT-3' \\
\hline 16 & cl-rpobU & 5'-GAAGGATCCACCATCGAATATCTGGTC-3' \\
\hline 17 & cl-rpobR & 5'-AAGCTTCTCCTCGTCGGCGGTCAGGT-3' \\
\hline 18 & Bla-U & 5'-CGTCGTTTGGTATGGCTTCATTC-3' \\
\hline 19 & Bla-R & 5'-AGGACCGAAGGAGCTAACCG-3' \\
\hline 20 & Bla-P & 5'-HEX-CGGTTCCCAACGATCAAGGCGAG-BHQ2-3' \\
\hline
\end{tabular}


The following amplification program was used: $96{ }^{\circ} \mathrm{C}-$ 10 minutes, then 50 cycles $96{ }^{\circ} \mathrm{C}-15$ seconds, $60{ }^{\circ} \mathrm{C}-$ 40 seconds, with final warming up during 10 minutes at $98^{\circ} \mathrm{C}$. After that, the droplets were read using the Droplet Reader unit, the obtained data was processed using the QuantaSoft software (Bio-Rad; USA).

\section{Loop-mediated isothermal amplification}

The reaction mixture with a volume of $20 \mu$ l contained $1 \times$ reaction buffer $(\mathrm{pH} 8,0)$ for Bst-polymerase (New England Biolabs; USA), 0,2 $\mu \mathrm{mol}$ of each outer primer (F3/B3), 0,4 $\mu \mathrm{mol}$ of each loop primer (LF/BF), 1,2 $\mu \mathrm{mol}$ of each inner primer (FIP/ $\mathrm{BIP})$, sequences of which are represented in Table 1, DNA matrix (1000 plasmid copies or 0,5-2 ng of mycobacterial DNA isolate for one reaction mixture), 2 activity units of Gss-polymerase from Geobacillus sp. 777 [15]. In the case of using LAMP in the real time mode the SYTO-9 intercalating dye bringing concentration to $2 \mu \mathrm{mol}$ was added [16]. The reaction was carried out in the CFX 96 amplifier (Bio-Rad; USA). The program included the following stages: primer annealing and elongation at $60{ }^{\circ} \mathrm{C}$ for 80 minutes with recording of the fluorescence signal once a minute on the FAM channel; determination of the melting point of amplification products in the range of $75-95^{\circ} \mathrm{C}$ after amplification for specificity analysis. To evaluate the isothermal amplification results the Tt (time-to-threshold - time needed by the accumulation curve of the amplification product to intersect the threshold value) parameter was used. All LAMP reactions were performed in three iterations, the table shows the mean values together with standard deviations for them.

\section{RESULTS}

We used two previously described $[17,18]$ schemes for the design of allele-specific isothermal loop amplification (ASLAMP) (Fig. 1). According to the first scheme, the detection of a mutation or a wild type allele is carried out using two allelespecific FIP primers. In the second scheme, allele-specific LAMP is initiated from a mutation-specific F3 primer. At the initial stage, we used plasmids with a cloned wild type rpoB fragment and a fragment containing the mutation as a matrix for working out the conditions. To optimize the reaction pS450L-M or pS450L-W with a concentration of 1000 copies per reaction served as a matrix for AS-LAMP. All optimization reactions were performed together with monitoring the accumulation of isothermal amplification products in real time using the SYTO9 intercalating dye. As the main parameter for optimization, the mutation discrimination index was used, which was defined as the difference in Tt for wild-type DNA and for mutant DNA when using the set of primers, including the allele-specific primer (ASFIP or AS-F3), for amplification.

In model experiments with the plasmid DNA, we have shown that the use of an analysis scheme using the allelespecific primer FIP compared to F3 has the best mutation discrimination index: the difference between the amplification time of the mutation and the wild type allele was $22 \pm 2,4$ versus $13 \pm 4,1$ minutes (Fig. 2). Use of non-parametric $U$-test (Mann-Whitney $U$-test) showed that the resulting discrimination indexes demonstrate the statistically significant difference $(p=0,0011)$. When using 100 DNA genomic equivalents a true positive signal (amplification of the rpoB gene with a mutation
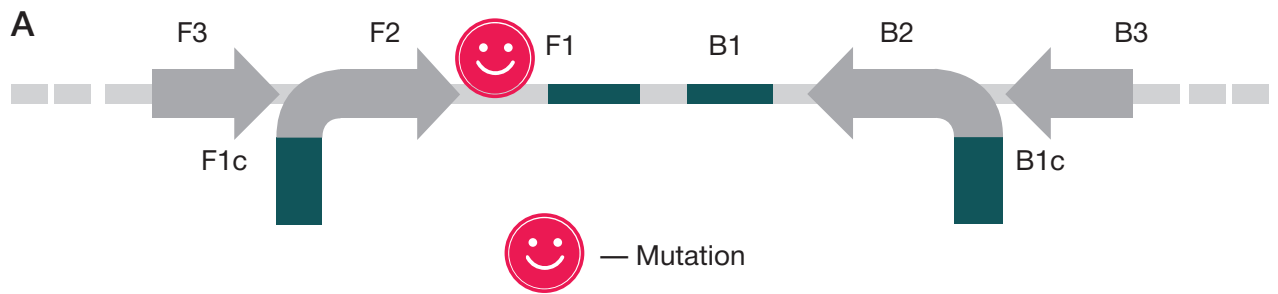

B

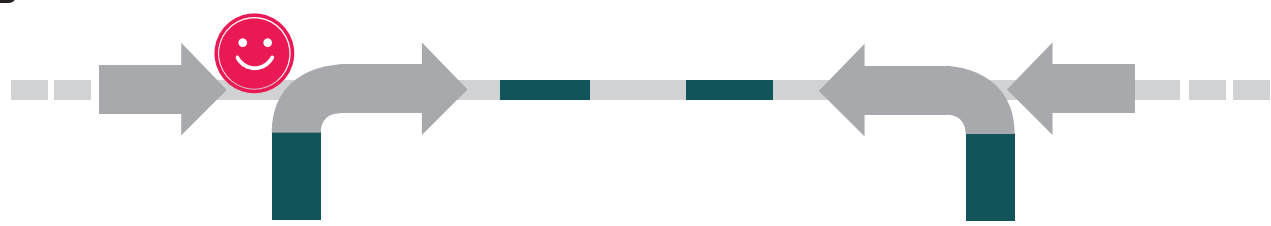

Fig. 1. Schematic illustration of the different principles of allele-specific isothermal loop amplification (AS-LAMP): allele-specific primer FIP (A), allele-specific primer F3 (B)

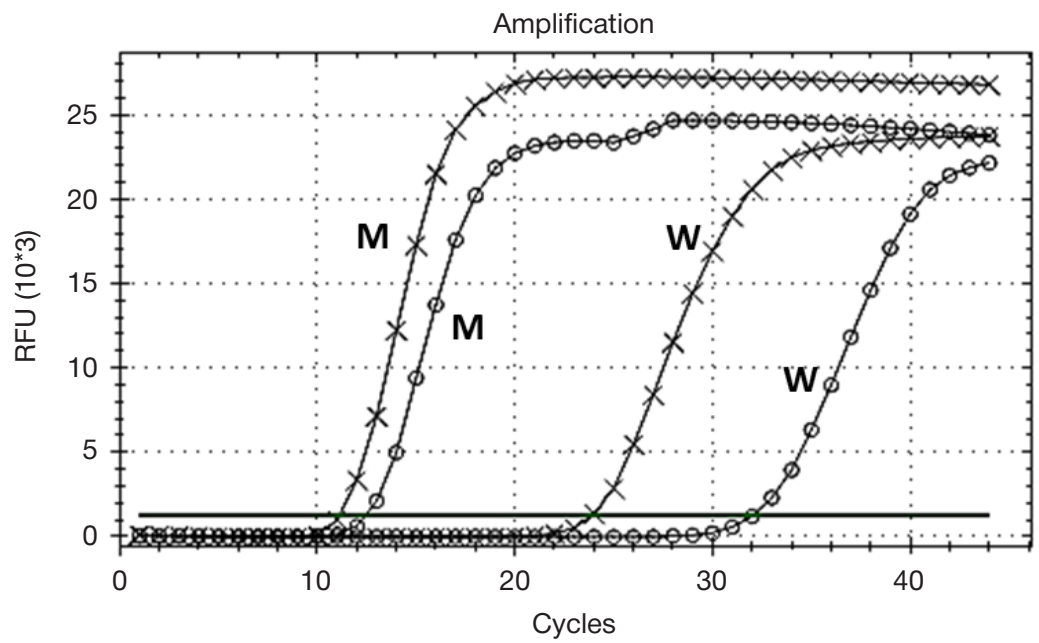

Fig. 2. Fluorescence accumulation curves for AS-LAMP products. Curves marked by circles correspond to FIP-AS-LAMP, marked by crosses — to F3-AS-LAMP 


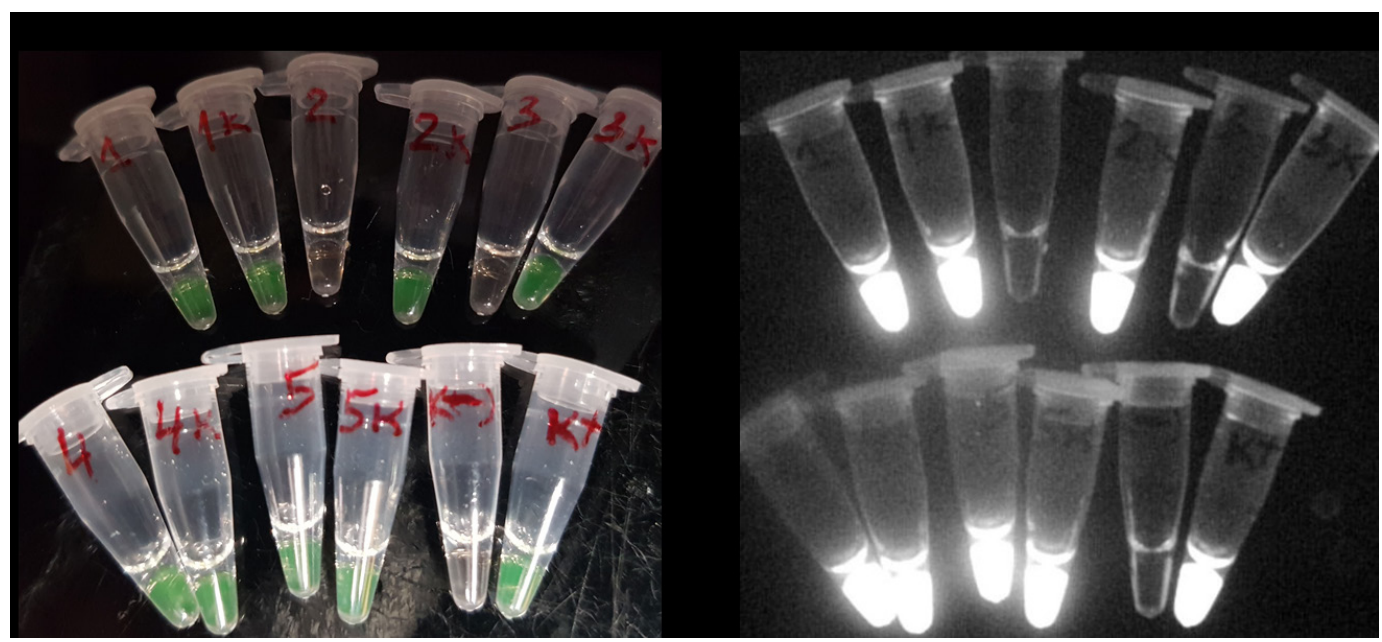

Fig. 3. Detection of TCG/TTG (S450L) mutation of the rpoB gene by AS-LAMP method with visualization of amplification products by adding the SYBR Green I intercalating dye in natural light (A) and with the $280 \mathrm{~nm}$ UV illumination (B). Samples 1, 4, 5 contain a mutation, 2 and $3-$ contain no mutation, they were amplified with mutation-specific primer, tubes marked with «K» were amplified with norm-specific primer

Table 2. The range of rpoB gene mutations of the Mycobacterium tuberculosis isolates detected by Sanger sequencing and the results of a TCG/TTG (S450L) mutation detection using AS-LAMP

\begin{tabular}{|c|l|c|c|}
\hline № & \multicolumn{1}{|c|}{ Mutation } & Sequencing & AS-LAMP \\
\hline 1 & No mutation & 18 & 18 \\
\hline 2 & Ser450Leu (TCG->TTG) & 20 & 0 \\
\hline 3 & His445Leu (CAC->CTC) & 4 & 0 \\
\hline 4 & His445GIn (CAC->CAA) & 1 & 0 \\
\hline 5 & Asp440Val (GAC->GTC) & 3 & 0 \\
\hline 6 & Asp440Asn (GAC->AAC) & 1 & 0 \\
\hline 7 & Asp440His (GAC->CAC) & 1 & 0 \\
\hline
\end{tabular}

when using the corresponding allele-specific primer) was detected after 29,4 $\pm 3,4$ minutes.

We also made an attempt to improve the mutation discrimination index by changing the concentration of betaine, as well as by adding dimethylsulfoxide (DMSO) which has the ability to increase the standard PCR specificity 19]. The optimal betaine concentration was 0,75 mol, adding DMSO did not improve the discrimination and even slightly increased the overall response time.

A positive signal was reliably visualized after adding SYBR Green I (at a concentration of 1: 1000 of commercial dye) to the reaction, both when illuminated with daylight and when using a UV transilluminator (Fig. 3). For further diagnostic validation, two reactions were performed for each test sample: the first one was AS-LAMP using the 531-FIP-M primer for mutation detection, the other one was using the 531-FIP-rpoB primer for Mycobacterium tuberculosis DNA detection. Reactions were performed either in a thermostat at $65{ }^{\circ} \mathrm{C}$ for 40 minutes with visualization of the reaction result using SYBR Green I or in real time (see the "Metods" chapter).

Using the developed method the DNA sample of 20 RIFR isolates from Mycobacterium tuberculosis was analyzed containing the Ser450Leu mutation in the rpoB gene, 10 RIFR $^{R}$ isolates containing other mutations in the rpoB gene (especially in His445 and Asp440 codons) as well as $18 \mathrm{RIF}^{\mathrm{s}}$ isolates without any mutations; the presence of mutations in the samples was determined using Sanger sequencing (Table 2). All tested samples were identified correctly, sensitivity and specificity of LAMP for detecting a Ser450Leu mutation in the rpoB gene was $100 \%$.

The use of AS-LAMP on a small sample of 11 DNA samples from the sputum of patients with active bacteria excretion showed complete concordance with the Sanger sequencing results (4 samples containing a mutation and 7 samples with no mutation).

Using human DNA as a matrix did not produce a sinificant signal.

It has been shown that analysis can be performed on crude lysates of bacterial cells. In this case, the total time of the analysis, starting from a biological sample, may not exceed 1,5 hour, given the fact that obtaining of crude mycobacterial lysates takes no more than 15-30 minutes.

\section{DISCUSSION}

In the past few years, several approaches have been proposed to identify single nucleotide DNA replacements using the LAMP method. All of them use allele-specific hybridization with amplification products [20, 21], allele-specific primers $[22,23]$ as well as the oligonucleotides selectively blocking the amplification of the studied structural variants [24].

Allele-specific polymerase chain reaction (AS-PCR) is one of the most widely used methods for DNA mutations detection [25]. Classical AS-PCR variant implies the use of two allele-specific primers, in which the $3^{\prime}$ - terminal nucleotide is complementary to the polymorphic nucleotide, and the third common primer. The method is based on the difference in the efficiency of paired and unpaired 3'-nucleotide elongation by DNA polymerase. Under ideal conditions (with complete elongation inhibition), this should lead to the absence of the amplification product in reaction with the primer to a mutation on the wild type DNA matrix.

To improve discrimination of products with "mutant" and "normal" DNA, the use of additional unpaired nucleotides at the 
3 '-end of the primer (at the $-2,-3$ or -4 position) is widely used for further destabilization of the duplex in order to reduce the efficiency of DNA polymerase elongation. We suggested that when elongating allele-specific primers with a chain-displacing DNA polymerase, a similar principle can be used. For the design of allele-specific primers, we chose the approach that was described in 2004. [26]. The authors proposed to increase the discrimination of the mutant allele by introduction of the second unpaired nucleotide at the -2 position of the allelespecific primer, as well as a simple set of rules for choosing the type of this base to achieve the maximum effect. Using these recommendations, we synthesized two fundamentally different sets of AS primers for isothermal loop amplification: the first one corresponds to FIP primer, the other one - to F3 primer.

Optimization of the detection of the TCG/TTG mutation (S450L) in the rpoB gene of Mycobacterium tuberculosis using the plasmid control DNA showed the preference of AS-FIP. Using it, we were able to classify all analyzed DNA samples of Mycobacterium tuberculosis isolates correctly, including the negative for TCG/TTG replacement (S450L) DNA samples carrying mutations in codons 445 and 440 , by visual analysis of the results of isothermal amplification in a standard thermostat that maintains temperature of $65^{\circ} \mathrm{C}$. AS-LAMP was also effective in detecting the Ser450Leu mutation of the rpoB gene in DNA from sputum of patients with known rpoB gene mutation status. We managed to classify 4 samples with the Ser450Leu mutation and 7 samples without this mutation correctly. The proposed approach showed high specificity and sensitivity to identify the most common Mycobacterium tuberculosis mutation causing resistance to rifampicin. Nevertheless, for a meaningful determination of the mentioned above parameters, it is necessary to test the method on a sample of a much larger scope.

Despite the fact that the overwhelming number of works on LAMP describes the qualitative detection of the presence of an infectious agent, this method also has a high potential for determining the structural polymorphism of the analyzed DNA. For example, it has been shown that it is possible to identify isolates of the Beijing Mycobacterium tuberculosis family using region RD207 and the Rv0679c gene as a target [27]. Our work contributes to the development of methods for identifying point mutations using LAMP and also increases the research potential of this method.

The limitations and disadvantages of the method proposed in this work include the need for additional validation of the method of extracting DNA and the associated amount of bacteria due to the dependence of the choice of the optimal analysis time, in which the positive signal of the mutationspecific system is not yet determined, on the mycobacterial DNA concentration.

\section{CONCLUSIONS}

We have demonstrated the fundamental possibility of determining mutations TCG/TTG (S450L) in the rpoB gene from Mycobacterium tuberculosis by allele-specific loop-mediated isothermal amplification method with high reliability without the use of expensive equipment. The total time required to test a clinical DNA sample may not exceed 1,5 hour.

\section{References}

1. Drobniewski FA, Wilson SM. The rapid diagnosis of isoniazid and rifampicin resistance in Mycobacterium tuberculosis - a molecular story. J Med Microbiol. 1998; 47 (3): 189-96.

2. Heifets LB. Antimycobacterial drugs. Semin Respir Infect. 1994; 9 (2): 84-103.

3. TB Drug Resistance Mutation Database. Available from: https:// tbdreamdb.ki.se/Data/MutationDetail.aspx?Areald=RIF\&GenelD=Rv0667.

4. Mokrousov I, Otten T, Vyshnevskiy B, Narvskaya O. Allelespecific rpoB PCR assays for detection of rifampin-resistant Mycobacterium tuberculosis in sputum smears. Antimicrob Agents Chemother. 2003; 47 (7): 2231-5

5. Filipenko ML, Dymova MA, Hrapov EA, Bojarskih, UA, Petrenko TI, Cherednichenko AG i dr. Sposob vyjavlenija ustojchivyh $k$ rifampicinu izoljatov. Vestnik NGU. 2012; 10 (2): 101-6.

6. Gill P, Ghaemi A. Nucleic acid isothermal amplification technologies: a review. Nucleosides Nucleotides Nucleic Acids 2008; 27 (3): 224-43.

7. Notomi T, Okayama $\mathrm{H}$, Masubuchi $\mathrm{H}$, Yonekawa $\mathrm{T}$, Watanabe $\mathrm{K}$, Amino $\mathrm{N}$ et al. Loop-mediated isothermal amplification of DNA. Nucleic Acids Res. 2000; 28 (12): E63.

8. Francois P, Tangomo M, Hibbs J, Bonetti E-J, Boehme CC Notomi $\mathrm{T}$ et. al. Robustness of a loop-mediated isothermal amplification reaction for diagnostic applications. FEMS Immunol Med Microbiol. 2011; 62 (1): 41-8.

9. Mori $Y$, Nagamine K, Tomita N, Notomi T. Detection of loopmediated isothermal amplification reaction by turbidity derived from magnesium pyrophosphate formation. Biochem Biophys Res Commun. 2001; 289 (1): 150-4.

10. Kouguchi Y, Fujiwara T, Teramoto M, Kuramoto M. Homogenous, real-time duplex loop-mediated isothermal amplification using a single fluorophore-labeled primer and an intercalator dye: Its application to the simultaneous detection of Shiga toxin genes 1 and 2 in Shiga toxigenic Escherichia coli isolates. Mol Cell Probes. 2010; 24 (4): 190-5.

11. Liu W, Huang S, Liu N, Dong D, Yang Z, Tang Y et al. Establishment of an accurate and fast detection method using molecular beacons in loop-mediated isothermal amplification assay. Sci Rep. 2017; (7): 40125 .

12. Goto M, Honda E, Ogura A, Nomoto A, Hanaki K-I. Colorimetric detection of loop-mediated isothermal amplification reaction by using hydroxy naphthol blue. Biotechniques. 2009; 46 (3): 167-72.

13. Nagai $K$, Horita $N$, Yamamoto $M$, Tsukahara $T$, Nagakura $H$, Tashiro $\mathrm{K}$ et al. Diagnostic test accuracy of loop-mediated isothermal amplification assay for Mycobacterium tuberculosis: systematic review and meta-analysis. Sci Rep. 2016; (6): 39090.

14. World Health Organization, editors. Global Tuberculosis Programme The use of loop-mediated isothermal amplification (TB-LAMP) for the diagnosis of pulmonary tuberculosis: policy quidance. 2016.

15. Oscorbin IP, Boyarskikh UA, Filipenko ML. Large fragment of DNA polymerase I from Geobacillus sp. 777: cloning and comparison with DNA polymerases I in practical applications. Mol Biotechnol. 2015; 57 (10): 947-59.

16. Oscorbin IP, Belousova EA, Zakabunin Al, Boyarskikh UA, Filipenko ML. Comparison of fluorescent intercalating dyes for quantitative loop-mediated isothermal amplification (qLAMP). Biotechniques. 2016; 61 (1): 20-5.

17. Badolo A, Bando H, Traoré A, Ko-ketsu M, Guelbeogo WM, Kanuka $\mathrm{H}$ et al. Detection of G119S ace-1 R mutation in fieldcollected Anopheles gambiae mosquitoes using allele-specific loop-mediated isothermal amplification (AS-LAMP) method. Malar J. 2015; (14): 477

18. Carlos FF, Veigas B, Matias AS, Doria G, Flores O, Baptista PV. Allele specific LAMP-gold nanoparticle for characterization of single nucleotide polymorphisms. Biotechnol Reports. 2017; (16): 21-5.

19. Chakrabarti R, Schutt CE. The enhancement of PCR amplification by low molecular-weight sulfones. Gene. 2001; 274 (1-2): 293-8.

20. Jiang YS, Bhadra S, Li B, Wu YR, Milligan JN, Ellington AD. Robust strand exchange reactions for the sequence-specific, 
real-time detection of nucleic acid amplicons. Anal Chem. 87 (6): 3314-20.

21. Nakamura N, Ito K, Takahashi M, Hashimoto K, Kawamoto M, Yamanaka $M$ et al. Detection of six single-nucleotide polymorphisms associated with rheumatoid arthritis by a loopmediated isothermal amplification method and an electrochemical DNA chip. Anal Chem. 2007; 79 (12): 9484-93.

22. Yongkiettrakul S, Kampeera J, Chareanchim W, Rattanajak R, Pornthanakasem W, Kiatpathomchai W et al. Simple detection of single nucleotide polymorphism in Plasmodium falciparum by SNP-LAMP assay combined with lateral flow dipstick. Parasitol Int. 2017; 66 (1): 964-71.

23. Zhang L, Zhang $Y$, Wang $C$, Feng $Q$, Fan F, Zhang G, et al. Integrated microcapillary for sample-to-answer nucleic acid pretreatment, amplification, and detection. Anal Chem. 2014; 86
(20): 10461-6.

24. Itonaga M, Matsuzaki I, Warigaya $\mathrm{K}$, Tamura $\mathrm{T}$, Shimizu $\mathrm{Y}$, Fujimoto M, et al. Novel methodology for rapid detection of KRAS mutation using PNA-LNA mediated loop-mediated isothermal amplification. PLoS One. 2016; (11): e0151654.

25. Newton CR, Graham A, Heptinstall LE, Powell SJ, Summers C, Kalsheker N, et al. Analysis of any point mutation in DNA. The amplification refractory mutation system (ARMS). Nucleic Acids Res. 1989; 17 (7): 2503-16.

26. Li B, Kadura I, Fu D-J, Watson DE. Genotyping with TaqMAMA. Genomics. 2004; 83 (2): 311-20.

27. Nagai Y, Iwade $Y$, Nakano M, Akachi S, Kobayashi T, Nishinaka T. Rapid and simple identification of Beijing genotype strain of Mycobacterium tuberculosis using a loop-mediated isothermal amplification assay. Microbiol Immunol. 2016; 60 (7): 459-67.

\section{Литература}

1. Drobniewski FA, Wilson SM. The rapid diagnosis of isoniazid and rifampicin resistance in Mycobacterium tuberculosis - a molecular story. J Med Microbiol. 1998; 47 (3): 189-96.

2. Heifets LB. Antimycobacterial drugs. Semin Respir Infect. 1994; 9 (2): 84-103.

3. TB Drug Resistance Mutation Database. Доступно по ссылке: https://tbdreamdb.ki.se/Data/MutationDetail.aspx?Areald=RIF\& GenelD=Rv0667.

4. Mokrousov I, Otten T, Vyshnevskiy B, Narvskaya O. Allelespecific rpoB PCR assays for detection of rifampin-resistant Mycobacterium tuberculosis in sputum smears. Antimicrob Agents Chemother. 2003; 47 (7): 2231-5

5. Филипенко М. Л., Дымова М. А., Храпов Е. А., Боярских, У. А., Петренко Т. И., Чередниченко А. Г. и др. Способ выявления устойчивых к рифампицину изолятов. Вестник НГУ. 2012; 10 (2): 101-6.

6. Gill P, Ghaemi A. Nucleic acid isothermal amplification technologies: a review. Nucleosides Nucleotides Nucleic Acids. 2008; 27 (3): 224-43.

7. Notomi T, Okayama H, Masubuchi H, Yonekawa T, Watanabe $\mathrm{K}$, Amino $\mathrm{N}$ et al. Loop-mediated isothermal amplification of DNA. Nucleic Acids Res. 2000; 28 (12): E63.

8. Francois P, Tangomo M, Hibbs J, Bonetti E-J, Boehme CC, Notomi $T$ et. al. Robustness of a loop-mediated isotherma amplification reaction for diagnostic applications. FEMS Immunol Med Microbiol. 2011; 62 (1): 41-8.

9. Mori Y, Nagamine K, Tomita N, Notomi T. Detection of loopmediated isothermal amplification reaction by turbidity derived from magnesium pyrophosphate formation. Biochem Biophys Res Commun. 2001; 289 (1): 150-4

10. Kouguchi $Y$, Fujiwara T, Teramoto M, Kuramoto M. Homogenous, real-time duplex loop-mediated isothermal amplification using a single fluorophore-labeled primer and an intercalator dye: Its application to the simultaneous detection of Shiga toxin genes 1 and 2 in Shiga toxigenic Escherichia coli isolates. Mol Cell Probes. 2010; 24 (4): 190-5.

11. Liu W, Huang S, Liu N, Dong D, Yang Z, Tang Y et al. Establishment of an accurate and fast detection method using molecular beacons in loop-mediated isothermal amplification assay. Sci Rep. 2017; (7): 40125

12. Goto M, Honda E, Ogura A, Nomoto A, Hanaki K-I. Colorimetric detection of loop-mediated isothermal amplification reaction by using hydroxy naphthol blue. Biotechniques. 2009; 46 (3): 167-72.

13. Nagai $K$, Horita N, Yamamoto $M$, Tsukahara T, Nagakura $H$, Tashiro $\mathrm{K}$ et al. Diagnostic test accuracy of loop-mediated isothermal amplification assay for Mycobacterium tuberculosis: systematic review and meta-analysis. Sci Rep. 2016; (6): 39090.

14. World Health Organization, editors. Global Tuberculosis Programme The use of loop-mediated isothermal amplification (TB-LAMP) for the diagnosis of pulmonary tuberculosis: policy guidance. 2016.

15. Oscorbin IP, Boyarskikh UA, Filipenko ML. Large fragment of DNA polymerase I from Geobacillus sp. 777: cloning and comparison with DNA polymerases I in practical applications. Mol Biotechnol. 2015; 57 (10): 947-59.

16. Oscorbin IP, Belousova EA, Zakabunin Al, Boyarskikh UA, Filipenko ML. Comparison of fluorescent intercalating dyes for quantitative loop-mediated isothermal amplification (qLAMP). Biotechniques. 2016; 61 (1): 20-5.

17. Badolo A, Bando H, Traoré A, Ko-ketsu M, Guelbeogo WM, Kanuka $\mathrm{H}$ et al. Detection of G119S ace-1 R mutation in fieldcollected Anopheles gambiae mosquitoes using allele-specific loop-mediated isothermal amplification (AS-LAMP) method. Malar J. 2015; (14): 477

18. Carlos FF, Veigas B, Matias AS, Doria G, Flores O, Baptista PV. Allele specific LAMP-gold nanoparticle for characterization of single nucleotide polymorphisms. Biotechnol Reports. 2017; (16): 21-5.

19. Chakrabarti R, Schutt CE. The enhancement of PCR amplification by low molecular-weight sulfones. Gene. 2001; 274 (1-2): 293-8.

20. Jiang $Y S$, Bhadra $S$, Li B, Wu YR, Milligan JN, Ellington AD. Robust strand exchange reactions for the sequence-specific, real-time detection of nucleic acid amplicons. Anal Chem. 87 (6): 3314-20.

21. Nakamura N, Ito K, Takahashi M, Hashimoto K, Kawamoto M, Yamanaka $M$ et al. Detection of six single-nucleotide polymorphisms associated with rheumatoid arthritis by a loopmediated isothermal amplification method and an electrochemical DNA chip. Anal Chem. 2007; 79 (12): 9484-93.

22. Yongkiettrakul S, Kampeera J, Chareanchim W, Rattanajak R, Pornthanakasem W, Kiatpathomchai W et al. Simple detection of single nucleotide polymorphism in Plasmodium falciparum by SNP-LAMP assay combined with lateral flow dipstick. Parasitol Int. 2017; 66 (1): 964-71.

23. Zhang L, Zhang $Y$, Wang $C$, Feng $Q$, Fan F, Zhang $G$, et al Integrated microcapillary for sample-to-answer nucleic acid pretreatment, amplification, and detection. Anal Chem. 2014; 86 (20): 10461-6.

24. Itonaga $M$, Matsuzaki I, Warigaya $K$, Tamura $T$, Shimizu $Y$, Fujimoto M, et al. Novel methodology for rapid detection of KRAS mutation using PNA-LNA mediated loop-mediated isothermal amplification. PLoS One. 2016; (11): e0151654.

25. Newton CR, Graham A, Heptinstall LE, Powell SJ, Summers C, Kalsheker $\mathrm{N}$, et al. Analysis of any point mutation in DNA. The amplification refractory mutation system (ARMS). Nucleic Acids Res. 1989; 17 (7): 2503-16.

26. Li B, Kadura I, Fu D-J, Watson DE. Genotyping with TaqMAMA. Genomics. 2004; 83 (2): 311-20.

27. Nagai $Y$, Iwade $Y$, Nakano M, Akachi S, Kobayashi T, Nishinaka T. Rapid and simple identification of Beijing genotype strain of Mycobacterium tuberculosis using a loop-mediated isothermal amplification assay. Microbiol Immunol. 2016; 60 (7): 459-67. 